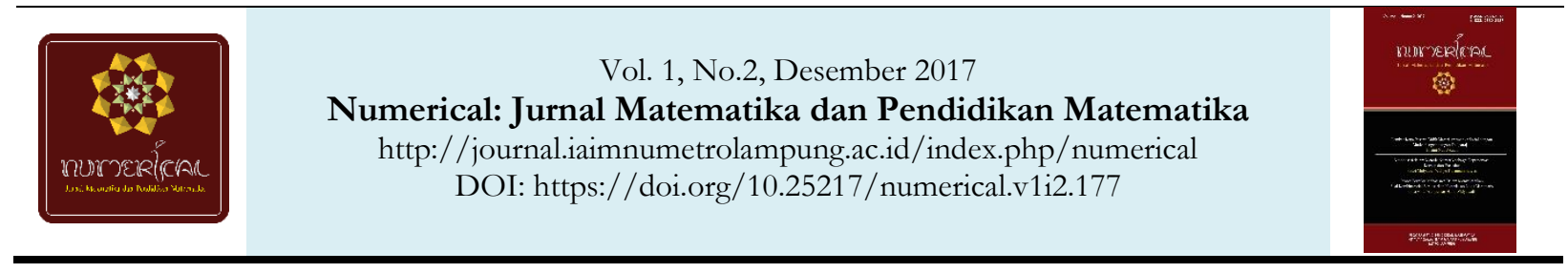

\title{
Proses Berpikir Mahasiswa Dalam Menyelesaikan Soal Kombinatorial Berdasarkan Kecerdasan Logis Matematis
}

\author{
Lilia Sinta Wahyuniar ${ }^{1}$, Santi Widyawati ${ }^{2}$
}

\author{
1) Universitas Nusantara PGRI Kediri, Indonesia \\ 2) Institut Agama Islam Ma'arif NU (IAIMNU) Metro, Indonesia \\ Correspondence: $\triangle$ li2asint@gmail.com
}

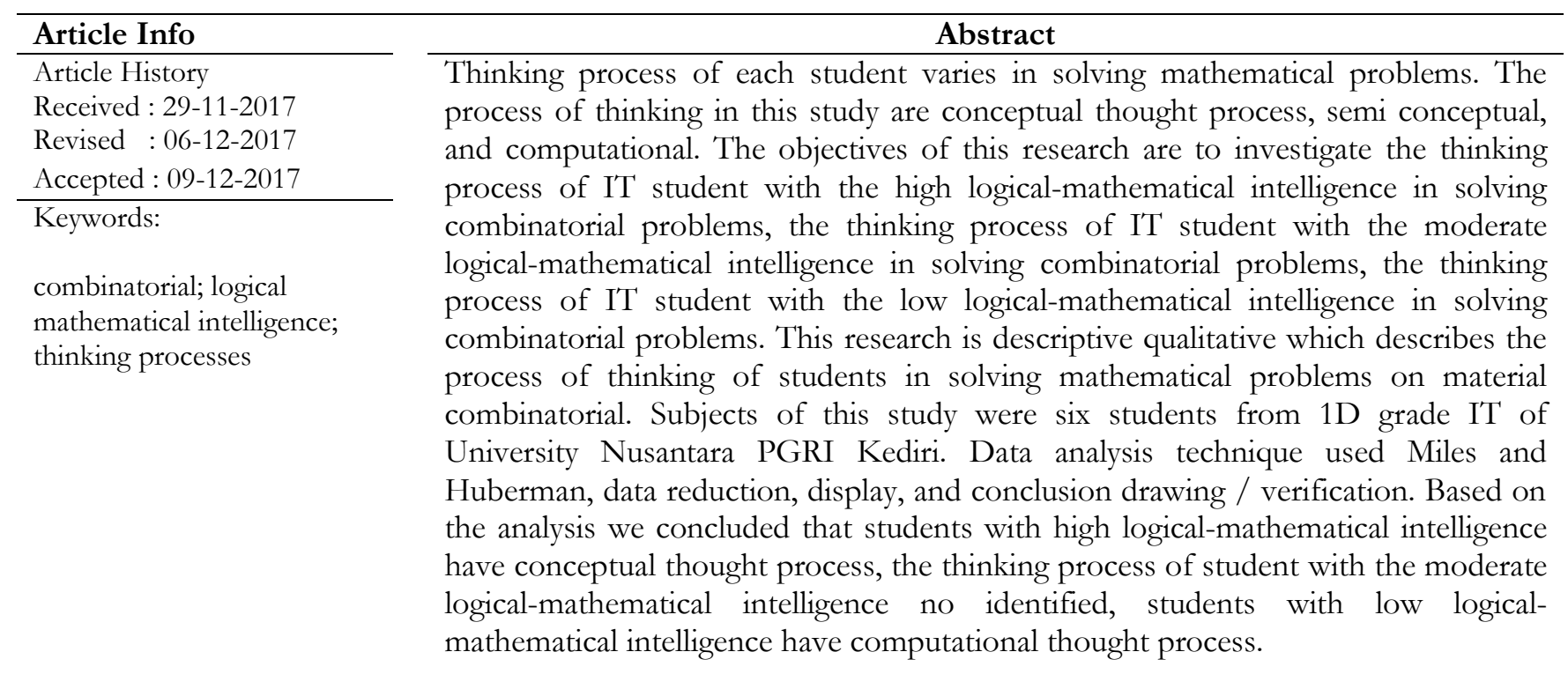

\section{PENDAHULUAN}

Dunia pendidikan saat ini sedang dihadapkan pada dua masalah besar, yaitu mutu pendidikan yang rendah dan sistem pembelajaran di sekolah yang kurang memadai. Dalam dunia pendidikan senantiasa mengalami perubahan yang terus-menerus dari tahun ketahun. Pendidikan pada dasarnya menyediakan lingkungan yang memungkinkan peserta didik untuk mengembangkan bakat dan kemampuan secara optimal, sehingga peserta didik dapat mewujudkan dan mengembangkan yang ada didalam dirinya sesuai dengan kebutuhan pribadi yang dilakukan dalam proses berilmu dan berpikir secara kreatif dan mandiri. Dalam hal ini faktor yang paling berpengaruh yaitu bisa dari dalam diri peserta didik seperti penalaran. Penalaran merupakan suatu kegiatan, suatu proses atau suatu aktivitas berpikir untuk menarik suatu kesimpulan atau membuat suatu pernyataan baru yang benar berdasar pada beberapa pernyataan yang kebenarannya telah dibuktikan atau diasumsikan sebelumnya [1]. Dalam hal ini siswa diharapkan mampu berpikir secara nalar dalam suatu proses pembelajaran, tidak ditujukan pada hasilnya saja.

Salah satu mata pelajaran yang diajarkan di sekolah salah satunya adalah pelajaran matematika. Matematika merupakan mata pelajaran yang diajarkan di setiap jenjang pendidikan formal dan 
merupakan bagian dari mata pelajaran wajib dalam pendidikan nasional. Matematika memiliki peran yang sangat penting karena matematika adalah ilmu dasar yang digunakan secara luas dalam berbagai bidang kehidupan. Tujuan mata pelajaran matematika dalam standar isi mata pelajaran matematika [2]. National Council of Teacher of Mathematich (NCTM) mengungkapkan bahwa kemampuan pemecahan masalah dan komunikasi matematis merupakan dua kemampuan yang harus dimiliki oleh siswa melalui pembelajaran matematika [3]. Adapun keterampilan-keterampilan yang perlu dimiliki oleh siswa melalui pembelajaran matematika yang di tetapkan oleh NCTM adalah pemecahan masalah, penalaran dan pembuktian, komunikasi, koneksi dan representasi. Maka diisyaratkan bahwa penalaran, pemecahan masalah dan komunikasi merupakan kompetensi yang harus dikuasai siswa setelah belajar matematika.

Berdasarkan hasil prasurvey yang dilakukan peneliti pada mahasiswa semester satu program studi Teknik Informatika Universitas Nusantara PGRI Kediri, setiap mahasiswa mempunyai karakter dan kemampuan penalaran yang berbeda-beda. Mahasiswa adalah makhluk yang unik, dimana antara mahasiswa yang satu dengan lain berbeda dalam banyak dimensi [4]. Dalam hal ini terdapat beberapa mahasiswa yang mengalami kesulitan dalam menyelesaikan soal matematika khususnya pada mata kuliah matematika diskrit materi kombinatorial. Dalam menyelesaikan soal matematika seseorang harus berpikir agar ia mampu memahami konsep-konsep matematika yang dipelajari serta mampu menggunakan atau menerapkan konsep-konsep tersebut secara tepat ketika ia harus mencari jawaban dari berbagai soal matematika. Dengan demikian, mahasiswa harus dilatih agar memiliki keterampilan daya berpikir yang baik, salah satunya dengan mengetahui proses berpikir pada masing-masing mahasiswa terutama pada matematika.

Proses berpikir merupakan proses yang digunakan seseorang dalam menerima informasi yang kemudian dari informasi tersebut di proses atau diolah untuk dicari kesimpulannya dan kesimpulan tersebut digunakan kembali untuk menyelesaikan masalah yang terkait untuk memecahkan masalah ingatan [4][6]. Menurut Zuhri [7] proses berpikir yang didasarkan dalam penyelesaian soal digolongkan menjadi tiga yaitu proses berpikir konseptual, proses berpikir semi konseptual dan proses berpikir komputasional. Proses berpikir konseptual merupakan cara berpikir siswa yang selalu menyelesaikan atau memecahakan masalah dengan menggunakan konsep yang dimiliki berdasarkan hasil pelajarannya atau hasil pemahamannya selama ini [8][9]. Proses berpikir semikonseptual merupakan cara berpikir siswa yang cenderung dalam menyelesaikan masalah menggunakan konsep tetapi belum sepenuhnya memahami konsep tersebut sehingga dalam menyelesaikan masalah dicampur dengan cara penyelesaian yang menggunakan intuisi dan proses berpikir komputasional merupakan cara berpikir yang pada umumnya dalam menyelesaikan masalah cenderung tidak menggunakan konsep tetapi mengandalkan intuisi [10].

Indikator-indikator yang dipakai untuk menelusuri proses berpikir konseptual, semikonseptual, dan komputasional adalah sebagai berikut [8] 
Tabel 1. Indikator Proses Berpikir

\begin{tabular}{|c|c|c|}
\hline Berpikir Konseptual & $\begin{array}{c}\text { Berpikir } \\
\text { Semikonseptual }\end{array}$ & Berpikir komputasional \\
\hline $\begin{array}{l}\text { Mampu menyatakan apa } \\
\text { yang diketahui dalam soal } \\
\text { dengan bahasa sendiri atau } \\
\text { mengubahnya dalam } \\
\text { kalimat matematika. (B.1.1) }\end{array}$ & \begin{tabular}{ll} 
Kurang & \multicolumn{2}{c}{ mampu } \\
menyatakan apa yang \\
diketahui dalam soal \\
dengan bahasa sendiri \\
atau mengubahnya dalam \\
kalimat \\
matematika.(B.2.1)
\end{tabular} & $\begin{array}{l}\text { Tidak mampu menyatakan } \\
\text { apa yang diketahui dalam } \\
\text { soal dengan bahasa sendiri } \\
\text { atau mengubahnya dalam } \\
\text { kalimat matematika. (B.3.1) }\end{array}$ \\
\hline $\begin{array}{l}\text { Mampu menyatakan apa } \\
\text { yang ditanya dalam soal } \\
\text { dengan bahasa sendiri atau } \\
\text { mengubahnya dalam } \\
\text { kalimat matematika. (B.1.2) }\end{array}$ & $\begin{array}{llr}\text { Kurang } & \text { mampu } \\
\text { menyatakan apa yang } \\
\text { ditanya dalam } \text { soal } \\
\text { dengan bahasa sendiri } \\
\text { atau mengubahnya dalam } \\
\text { kalimat matematika. } \\
\text { (B.2.2) }\end{array}$ & $\begin{array}{l}\text { Tidak mampu menyatakan } \\
\text { apa yang ditanya dalam soal } \\
\text { dengan bahasa sendiri atau } \\
\text { mengubahnya dalam kalimat } \\
\text { matematika. (B.3.2) }\end{array}$ \\
\hline $\begin{array}{l}\text { Mampu membuat rencana } \\
\text { penyelesaian dengan } \\
\text { lengkap. (B.1.3) }\end{array}$ & $\begin{array}{l}\text { Membuat rencana } \\
\text { penyelesaian tetapi tidak } \\
\text { lengkap. (B.2.3) }\end{array}$ & $\begin{array}{lr}\text { Tidak membuat } & \text { rencana } \\
\text { penyelesaian } & \text { dengan } \\
\text { lengkap. (B.3.3) } & \\
\end{array}$ \\
\hline $\begin{array}{l}\text { Mampu menyatakan } \\
\text { langkah-langkah yang } \\
\text { ditempuh dalam } \\
\text { menyelesaikan soal } \\
\text { menggunakan konsep yang } \\
\text { pernah dipelajari. (B.1.4) }\end{array}$ & $\begin{array}{lr}\text { Kurang } & \text { mampu } \\
\text { menyatakan langkah- } \\
\text { langkah yang ditempuh } \\
\text { dalam menyelesaikan soal } \\
\text { menggunakan konsep } \\
\text { yang pernah dipelajari. } \\
\text { (B.2.4) }\end{array}$ & $\begin{array}{lr}\text { Tidak mampu menyatakan } \\
\text { langkah-langkah yang } \\
\text { ditempuh } \\
\text { menyelesaikan dalam } \\
\text { menggunakan konsep yang } \\
\text { pernah dipelajari. (B.3.4) }\end{array}$ \\
\hline $\begin{array}{l}\text { Mampu memeriksa kembali } \\
\text { kebenaran atau mengoreksi } \\
\text { kesalahan dari setiap } \\
\text { langkah penyelesaian } \\
\text { sehingga diperoleh hasil } \\
\text { yang benar. (B.1.5) }\end{array}$ & 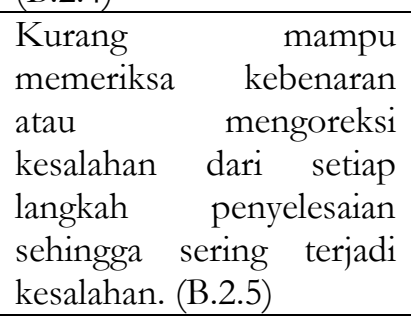 & $\begin{array}{lr}\text { Tidak memeriksa } & \text { atau } \\
\text { mengoreksi } & \text { kembali } \\
\text { penyelesaian yang dibuat. } \\
\text { (B.3.5) }\end{array}$ \\
\hline
\end{tabular}

Tayler menyatakan bahwa pada dasarnya setiap individu berbeda satu dengan yang lain, dimensidimensi perbedaan individu antara lain adalah intelegensi, kemampuan berpikir logis, kreativitas, gaya kognitif, kepribadian, nilai, sikap dan minat [11]. Kecerdasan itu sebagai potensi biopsikologi. Artinya, semua anggota jenis makhluk hidup yang bersangkutan mempunyai potensi untuk menggunakan sekumpulan bakat kecerdasan yang dimiliki oleh jenis makhluk itu [12]. Kecerdasan logis matematis adalah kecerdasan yang memuat kemampuan seseorang yang berpikir dalamkemampuan berpikir menurut aturan logika, memahami dan menganalisa pola angka-angka serta memecahkan masalah dengan menggunakan kemampuan berpikir [13][14]. Menurut Jasmin kecerdasan logis matematis berhubungan dengan dan mencakup kemampuan ilmiah. Ciri-ciri orang yang kecerdasan logismatematisnya menonjol antara lain memiliki kemampuan yang mumpuni dalam penalaran, mengurutkan, berpikir dalam pola sebab akibat, menciptakan hipotesis, mencari keteraturan konseptual atau pola numerik dan bahkan biasanya, pandangan hidupnya bersifat rasional [15]. Tujuan penelitian ini untuk mengetahui proses berpikir mahasiswa TI yang mempunyai kecerdasan logis matematis tinggi dalam menyelesaikan soal kombinatorial, untuk mengetahui proses berpikir mahasiswa TI yang 
mempunyai kecerdasan logis matematis sedang dalam menyelesaikan soal kombinatorial, untuk mengetahui proses berpikir mahasiswa TI yang mempunyai kecerdasan logis matematis rendah dalam menyelesaikan soal kombinatorial.

\section{METODE}

Dalam penelitian ini menggunakan jenis pendekatan deskriptif kualitatif. Menurut Bodgam dan Taylor [16] penelitian kualitatif adalah prosedur penelitiannya menghasilkan data deskriptif berupa katakata tertulis atau lisan dari orang-orang atau tentang perilaku yang diamati. Disebut deskriptif karena akan mendeskripsikan bagaimana proses berpikir mahasiswa TI kelas 1D dalam menyelesaikan soal kombinatorial. Data yang diperoleh dalam penelitian ini berupa hasil pekerjaan mahasiswa dalam menyelesaikan soal yang berkaitan dengan materi kombinatorial secara tertulis dan hasil wawancara yang dilakukan oleh peneliti dengan subjek penelitian setelah subjek penelitian mengerjakan soal tersebut.

Dalam menentukan subjek penelitian ini dipilih dengan metode purposive sampling yaitu pengambilan subjek yang berorientasi pada tujuan. Sehingga ditetapkan beberapa prosedur yang telah ditetapkan oleh peneliti untuk mempermudah proses berlangsungnya penelitian. Hal tersebut dikarenakan kecederungan peneliti untuk memilih informannya berdasarkan posisi dengan akses tertentu yang dianggap memiliki informasi yang berkaitan dengan permasalahan secara mendalam dan dapat dipercaya untuk menjadi sumber data yang mantap [17]. Subjek pada penelitian ini adalah mahasiswa TI kelas 1D Universitas Nusantara PGRI Kediri yang sudah memperoleh mata kuliah matematika diskrit materi kombinatorial.

Mahasiswa TI yang sudah dipilih diberikan soal uraian mengenai materi kombinatorial sebanyak 3 soal mengenai kaidah penjumlahan dan perkalian, permutasi dan kombinatorial, yang kemudian nanti jawaban mahasiswa tersebut akan dianalisis. Untuk mengklarifikasi hasil analisis jawaban tertulis mahasiswa, maka dilakukan wawancara pada tiap mahasiswa tersebut terkait pekerjaan yang sudah dikerjakan. Hal ini bertujuan untuk mengetahui langkah-langkah atau proses berpikirmahasiswa. Menurut Lofland [18] sumber data utama dalam penelitian kualitatif adalah kata-kata dan tindakan selebihnya adalah data tambahan seperti dokumen dan lain-lain. Data yang dikumpulkan tersebut berupa hasil tes tertulis serta hasil wawancara.

Instrumen dalam penelitian ini dibedakan menjadi dua bagian yaitu instrumen utama dalam penelitian ini adalah peneliti sendiri sedangkan instrumen bantu berupa instrumen bantu I yaitu testertulis materi kombinatorial dan instrumen bantu II yaitu berupa pedoman wawancara. Teknik keabsahan data yang digunakan dalam penelitian ini yaitu dengan triangulasi metode. Dari hasil tes tertulis dan hasil wawancara dari seorang subjek dibandingkan dan ditarik kesimpulan data yang lebih kuat validitasnya. Analisis data yang dilakukan peneliti selama dan setelah pengumpulan data dengan melaksanakan tiga kegiatan dengan mengikuti konsep Miles dan Huberman [17] yaitu reduksi data, penyajian data, verifikasi (pengecekan) data dan penarikan kesimpulan.

\section{HASIL PENELITIAN DAN PEMBAHASAN}

Hasil dari penelitian ini menunjukkan bahwa mahasiswa dengan masing-masing kecerdasan logis matematis memiliki proses berpikir tentang kombinatorial yang berbeda. Ini terlihat dari jawabanjawaban yang diberikan ketika diberikan soal tes sebagai berikut:

1. Tersedia 6 huruf: a, b, c, d, e, f. Berapa jumlah pengurutan 3 huruf jika :

a. Tidak boleh ada huruf yang diulang

b. Boleh ada huruf yang berulang

2. Diantara 10 orang mahasiswa Teknik Informatika Angkatan 2016, berapa banyak cara membentuk sebuah perwakilan beranggotakan 5 orang sedemikian sehingga:

a. Mahasiswa bernama A selalu termasuk didalamnya, tetapi B tidak

b. Mahasiswa bernama A dan B selalu termasuk didalamnya 
Numerical: Jurnal Matematika dan Pendidikan Matematika, Vol. 1 No. 2 Desember 2017, 103-114

Lilia Sinta Wahyuniar, Santi Widyawati

3. 12 buah lampu berwarna ( 4 merah, 3 putih, dan 5 biru) dipasang pada 12 buah soket dalam sebuah baris. Berapa jumlah cara pengaturan lampu?

Berikut ini adalah analisis proses berfikir mahasiswa dari masing-masing kecerdasan logis matematis:

a. Deskripsi dan analisis proses berpikir mahasiswa subjek dengan inisial RE dan MADP dengan kecerdasan logis matematis rendah

Berikut ini hasil jawaban yang diberikan subjek RE:

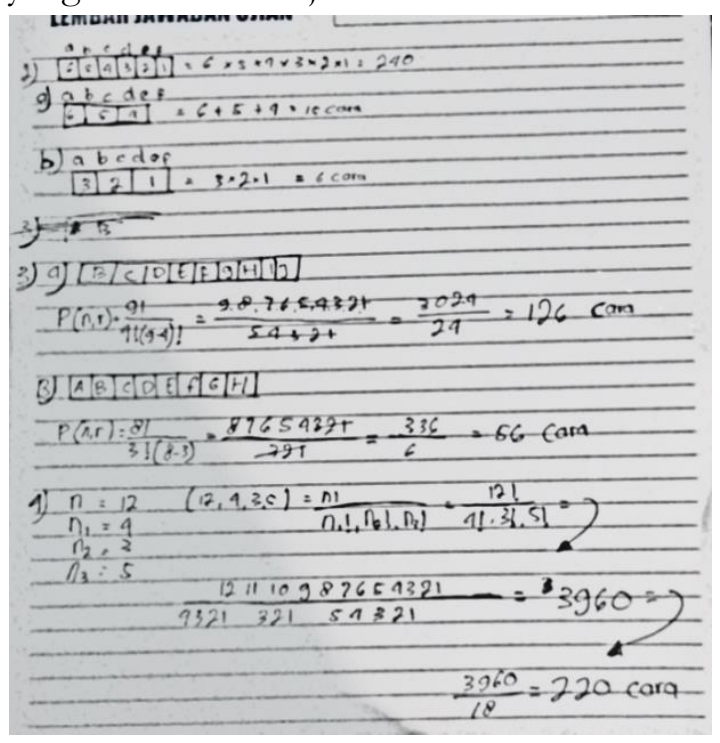

Gambar 1. Jawaban subjek RE

Jawaban diatas merupakan sampel dari hasil pekerjaan mahasiswa dalam menyelesaikan soal yang berkaitan dengan materi kombinatorial secara tertulis. Dari jawaban tersebut menunjukan bahwa peserta didik belum sepenuhnya menguasi materi. Untuk mengklarifikasi hasil analisis jawaban tertulis tersebut, maka dilakukan wawancara terkait pekerjaan yang sudah dikerjakan. Semua itu dilakukan untuk mengidetentifikasi konsep atau rumus matematika yang terlibat dalam soal kombinatorial.

Mahasiswa RE tidak mampu menerapkan kaidah dasar penghitungan (perkalian dan penjumlahan) dimanamasih bingung dalam menyelesaikan permasalahan permutasi dalam bentuk sederhana serta tidak mampu menyelesaikan permasalahan permutasi dalam soal yang agak rumit, tidak mampu menyelesaikan permasalahan kombinasi dengan berbagai variasi, tidak dapat menjelaskan dengan kalimat sendiri ketika ditanya bagaimana cara membedakan bahwa suatu soal termasuk permutasi atau kombinasi. Mahasiswa RE cenderung mempunyai proses berpikir komputasional karena mempunyai ciri-ciri seperti pada indikator yaitu tidak dapat mengungkapkan apa yang diketahui dalam soal kombinatorial dengan kalimat sendiri, tidak mampu mengungkapkan dengan kalimat sendiri yang ditanya dalam soal kombinatorial, dalam menjawab soal kombinatorial cenderung lepas dari konsep atau rumus yang sudah dipelajari (tidak membuat rencana penyelesaian dengan lengkap), tidak mampu menjelaskan langkah-langkah yang ditempuh dalam menyelesaikan soal kombinatorial, tidak memeriksa atau mengoreksi kembali penyelesaian yang dibuat. 
Berikut ini hasil jawaban yang diberikan subjek MADP:

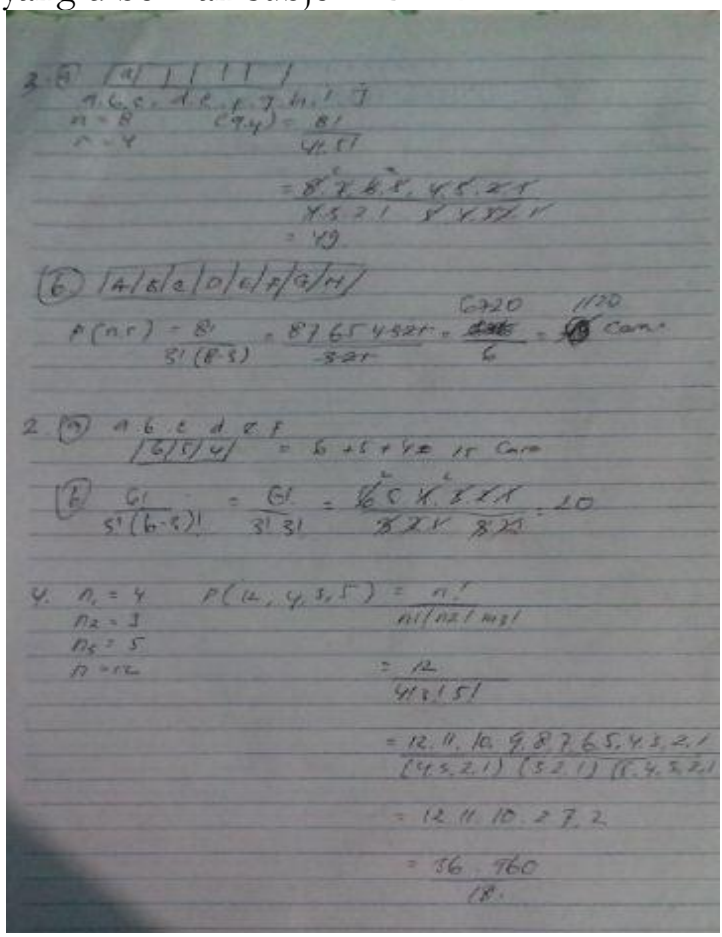

Gambar 2. Jawaban Subjek MADP

Mahasiswa MADP tidak mampu menerapkan kaidah dasar penghitungan (perkalian dan penjumlahan), tidak mampu menjelaskan dengan kalimat sendiri apa yang dimaksud dengan kaidah dasar penghitungan, tidak mampu menyelesaikan permasalahan permutasi dalam soal yang agak rumit, bingung dalam menyelesaikan permasalahan kombinasi dalam bentuk yang sederhana serta tidak mampu menyelesaikan permasalahan kombinasi dalam soal yang agak rumit, tidak dapat menjelaskan dengan kalimat sendiri ketika ditanya bagaimana cara membedakan bahwa suatu soal termasuk permutasi atau kombinasi. Mahasiswa MADP cenderung mempunyai proses berpikir komputasional karena mempunyai ciri-ciri seperti pada indikator yaitu tidak dapat mengungkapkan apa yang diketahui dalam soal kombinatorial dengan kalimat sendiri, tidak mampu mengungkapkan dengan kalimat sendiri yang ditanya dalam soal kombinatorial, dalam menjawab soal kombinatorial cenderung lepas dari konsep atau rumus yang sudah dipelajari (tidak membuat rencana penyelesaian dengan lengkap), tidak mampu menjelaskan langkah-langkah yang ditempuh dalam menyelesaikan soal kombinatorial, tidak memeriksa atau mengoreksi kembali penyelesaian yang dibuat.

b. Deskripsi dan analisis proses berpikir mahasiswa subjek dengan inisial TIDN dan DANT dengan kecerdasan logis matematis sedang.

Berikut ini hasil jawaban yang diberikan subjek TIDN: 
Numerical: Jurnal Matematika dan Pendidikan Matematika, Vol. 1 No. 2 Desember 2017, 103-114

Lilia Sinta Wahyuniar, Santi Widyawati

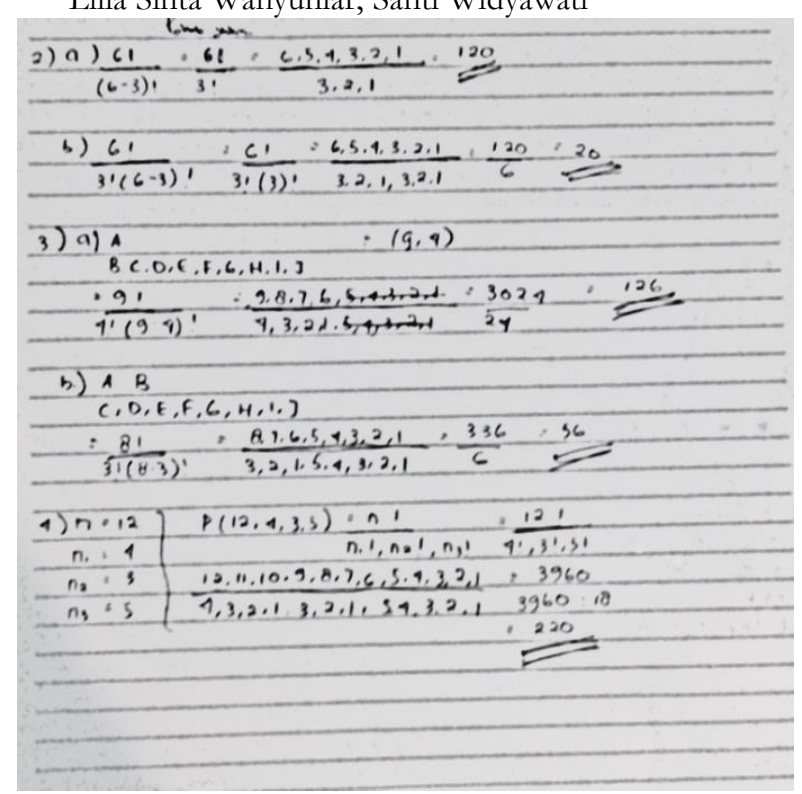

Gambar 2. Jawaban subjek TIDN

Berdasarkan hasil jawaban yang ada dan kemudian untuk mengklarifikasi hasil analisis jawaban tertulis tersebut, maka dilakukan wawancara terkait pekerjaan yang sudah dikerjakan. Semua itu dilakukan untuk mengidetentifikasi konsep atau rumus matematika yang terlibat dalam soal kombinatorial.

Mahasiswa TIDN mampu menerapkan kaidah dasar penghitungan (perkalian dan penjumlahan) dalam menyelesaikan soal tetapi tidak mampu menjelaskan dengan kalimat sendiri apa yang dimaksud dengan kaidah dasar penghitungan, mampu menyelesaikan permasalahan permutasi dalam bentuk sederhana tetapi tidak mampu menyelesaikan permasalahan permutasi dalam soal yang rumit, tidak mampu menyelesaikan permasalahan kombinasi dengan berbagai variasi, tidakmampu menjelaskan dengan kalimat sendiri ketika ditanya bagaimana cara membedakan bahwa suatu soal termasuk permutasi atau kombinasi. Proses berpikir mahasiswa TIDN tidak dapat dikategorikan karena tidak sesuai dengan indikator dari ketiga proses berpikir yang dimaksud, seperti yang sudah dijabarkan bahwa mahasiswa TIDN mempunyai ciri-ciri yaitu kurang mampu mengungkapkan apa yang diketahui dalam soal kombinatorial dengan kalimat sendiri, tidak mampu mengungkapkan dengan kalimat sendiri apa yang ditanya dalam soal kombinatorial, dalam menjawab soal kombinatorial kurang mampu menggunakan dari konsep atau rumus yang sudah dipelajariserta banyak yang lepas dari konsep atau rumus yang sudah dipelajari, tidak mampu menjelaskan langkah-langkah yang ditempuh dalam menyelesaikan soal kombinatorial.

Berikut ini hasil jawaban yang diberikan subjek DANT: 


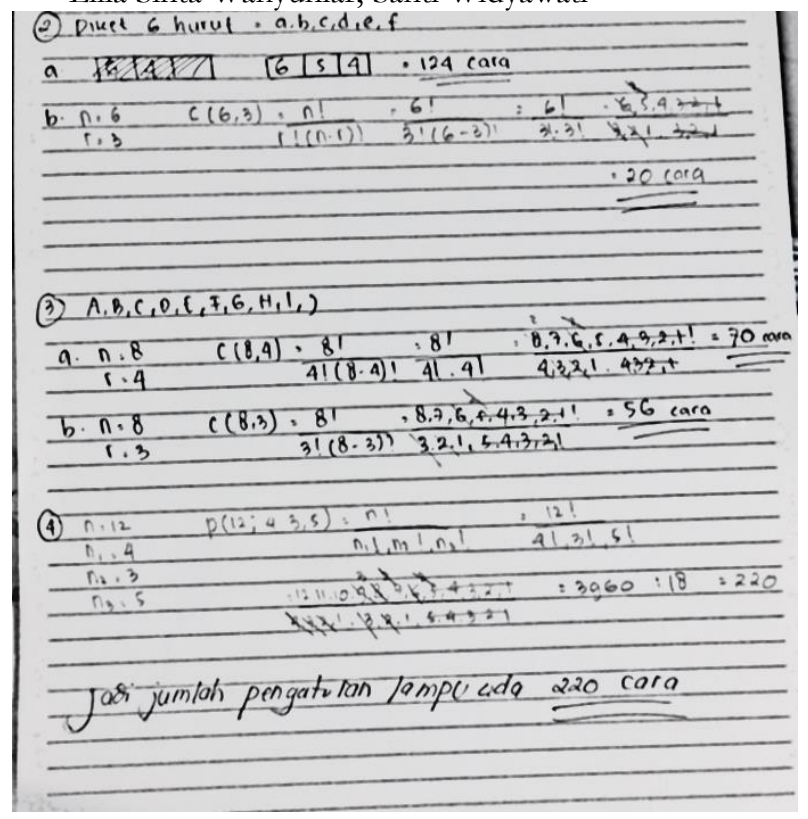

Gambar 3. Jawaban subjek DANT

Mahasiswa DANT kurang mampu menerapkan kaidah dasar penghitungan (perkalian dan penjumlahan) dalam menyelesaikan soal serta kurang mampu menjelaskan dengan kalimat sendiri apa yang dimaksud dengan kaidah dasar penghitungan walaupun masih adayang keluar dari konsep atau rumus, kurang mampu menyelesaikan permasalahan dengan berbagai variasi, kurang mampu menyelesaikan permasalahan kombinasi dengan berbagai variasi, mampu menjelaskan dengan kalimat sendiri ketika ditanya bagaimana cara membedakan bahwa suatu soal termasuk permutasi atau kombinasi walaupun masih ada keraguan dalam menjawab. Mahasiswa DANT cenderung mempunyai proses berpikir semi konseptual karena mempunyai ciri-ciri seperti pada indikator yaitu kurang dapat mengungkapkan apa yang diketahui dalam soal kombinatorial dengan kalimat sendiri, kurang mampu mengungkapkan dengan kalimat sendiri yang ditanya dalam soal kombinatorial, dalam menjawab soal kombinatorial cenderung menggunakan dari konsep atau rumus yang sudah dipelajari walaupun tidak lengkap, tidak sepenuhnya mampu menjelaskan langkah-langkah yang ditempuh dalam menyelesaikan soal kombinatorial, kurang mampu memeriksa kebenaran atau mengoreksi kesalahan dari setiap langkah penyelesaian sehingga sering terjadi kesalahan.

c. Deskripsi dan analisis proses berpikir mahasiswa subjek dengan inisial MAA dan RS dengan kecerdasan logis matematis tinggi.

Berikut ini hasil jawaban yang diberikan subjek MAA: 
Numerical: Jurnal Matematika dan Pendidikan Matematika, Vol. 1 No. 2 Desember 2017, 103-114

Lilia Sinta Wahyuniar, Santi Widyawati

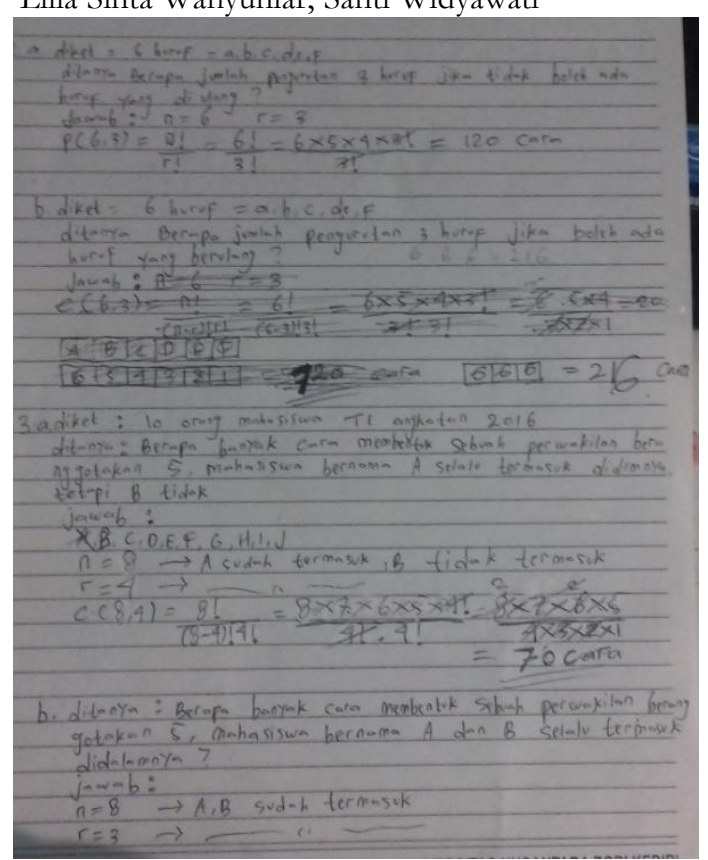

Gambar 4. Jawaban subjek MAA

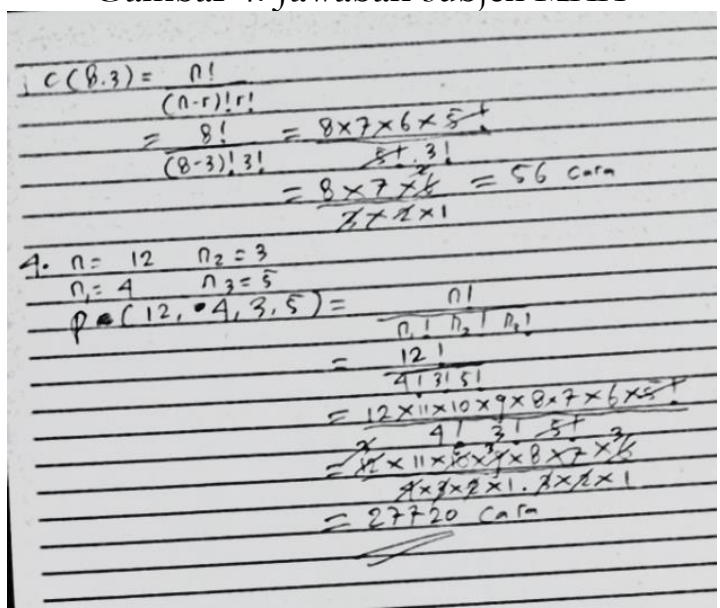

Gambar 5. Jawaban subjek MAA

Berdasarkan hasil jawaban yang ada dan kemudian untuk mengklarifikasi hasil analisis jawaban tertulis tersebut, maka dilakukan wawancara terkait pekerjaan yang sudah dikerjakan. Semua itu dilakukan untuk mengidetentifikasi konsep atau rumus matematika yang terlibat dalam soal kombinatorial.

Mahasiswa MAA mampu menerapkan kaidah dasar penghitungan (perkalian dan penjumlahan) dalam menyelesaikan soal kombinatorial dalam bentuk sederhana dan yang disertai perluasan, serta mampu menjelaskan dengan kalimat sendiri apa yang dimaksud dengan kaidah dasar penghitungan, mampu menyelesaikan permasalahan permutasi dalam bentuk sederhana maupun soal yang rumit, mampu menyelesaikan permasalahan kombinasi dengan berbagai variasi, mampu mengungkapkan dengan kalimat sendiri apa yang diketahui dalm soal kombinatorial, mampu menjelaskan dengan kalimat sendiri ketika ditanya bagaimana cara membedakan bahwa suatu soal termasuk permutasi atau kombinasi, mampu memberikan contoh soal mengenai kombinatorial beserta jawaban. Mahasiswa MAA cenderung mempunyai proses berpikir konseptual karena mempunyai ciri-ciri seperti pada indikator yaitu mampu mengungkapkan apa yang diketahui dalam soal kombinatorial dengan kalimat sendiri, mampu mengungkapkan dengan kalimat sendiri yang ditanya dalam soal kombinatorial, dalam menjawab soal kombinatorial mampu 
menggunakan dari konsep atau rumus yang sudah dipelajari, mampu menjelaskan langkah-langkah yang ditempuh dalam menyelesaikan soal kombinatorial, mampu memeriksa kebenaran atau mengoreksi kesalahan dari setiap langkah penyelesaian sehingga sering terjadi kesalahan.

Berikut ini hasil jawaban yang diberikan subjek MAA:

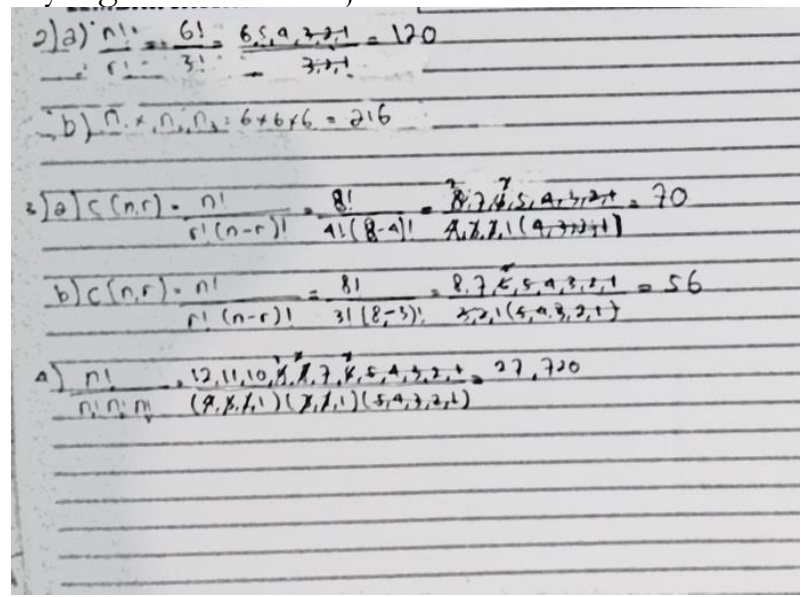

Gambar 6. Jawaban subjek RS

Mahasiswa RS mampu menerapkan kaidah dasar penghitungan (perkalian dan penjumlahan) dalam menyelesaikan soal kombinatorial dalam bentuk sederhana dan yang disertai perluasan, serta mampu menjelaskan dengan kalimat sendiri apa yang dimaksud dengan kaidah dasar penghitungan, mampu menyelesaikan permasalahan permutasi dalam bentuk sederhana maupun soal yang rumit, mampu menyelesaikan permasalahan kombinasi dengan berbagai variasi, mampu mengungkapkan dengan kalimat sendiri apa yang diketahui dalm soal kombinatorial, mampu menjelaskan dengan kalimat sendiri ketika ditanya bagaimana cara membedakan bahwa suatu soal termasuk permutasi atau kombinasi, mampu memberikan contoh soal mengenai kombinatorial beserta jawaban. Mahasiswa RS cenderung mempunyai proses berpikir konseptual karena mempunyai ciri-ciri seperti pada indikator yaitu mampu mengungkapkan apa yang diketahui dalam soal kombinatorial dengan kalimat sendiri, mampu mengungkapkan dengan kalimat sendiri yang ditanya dalam soal kombinatorial, dalam menjawab soal kombinatorial mampu menggunakan dari konsep atau rumus yang sudah dipelajari, mampu menjelaskan langkah-langkah yang ditempuh dalam menyelesaikan soal kombinatorial, mampu memeriksa kebenaran atau mengoreksi kesalahan dari setiap langkah penyelesaian sehingga sering terjadi kesalahan.

Berdasarkan uraian yang telah dijabarkan dapat disimpulkan bahwa mahasiswa dengan kecerdasan logis matematis tinggi mempunyai proses berpikir konseptual, proses berpikir mahasiswa dengan kecerdasan logis matematis sedang tidak teridentifikasi, mahasiswa dengan kecerdasan logis matematis rendah mempunyai proses berpikir komputasional. Hal ini berarti bahwa mahasiswa yang mempunyai kecerdasan logis matematis tinggi/baik mampu mengerjakan dan menyelesaikan soal-soal yang memuat angka-angka serta mampu menyelesaikan dengan langkah-langkah yang sudah dipelajari. Seperti hasil penelitian sebelumnya menunjukkan bahwa proses berpikir siswa dari kelompok atas cenderung berpikir konseptual dalam menyelesaikan soal cerita dan siswa dari kelompok tengah dalam menyelesaikan soal cerita pada materi pecahan cenderung pada proses berpikir semikonseptual [5]. Sedangkan proses berpikir siswa dari kelompok bawah dalam menyelesaikan soal soal cerita pada materi pecahan cenderung pada proses berpikir komputasional. Seseorang yang memiliki kecerdasan logis matematis yang tinggi akan berprestasi dalam pelajaran matematika dan menikmati kemajuan teknologi dalam penggunaan program software logika [19].

Siswa yang memiliki kecerdasan logis matematis cenderung menyenangi kegiatan menganalisis dan mempelajari sebab akibat terjadinya sesuatu [20]. Ia menyenangi berpikir secara konseptual, misalnya menyusun hipotesis dan mengadakan kategorisasi dan klasifikasi terhadap apa yang

Copyright (C) 2017, Numerical: Jurnal Matematika dan Pendidikan Matematika Print ISSN: 2580-3573, Online ISSN: 2580-2437 
dihadapinya. Kecerdasan logis matematis adalah kecerdasan dimana seseorang dituntut untuk mengoperasi suatu bilangan dengan cepat dan tepat, menghitung angka-angka yang sangat rumit, dapat menganalisis sebab-akibat terjadinya sesuatu dan mampu merumuskan masalah yang ada sehingga seseorang yang berkecerdasan logis matematis akan dapat berpikir sesuai dengan hal-hal yang bersifat rasional [21]. Jenis-jenis proses yang digunakan dalam pelayanan kecerdasan logis matematis mencakup kategorisasi, klasifikasi, kesimpulan, generalisasi, penghitungan dan pengujian hipotesis [22]. Gaya belajar anak dengan kecenderungan kecerdasan logis matematis adalah belajar dengan angka-angka, belajar dengan menggunakan komputer, belajar dengan membuat hipotesis atau pikiran terlebih dahulu, belajar melalui kasus dan berusaha mencari jalan keluar [23].

\section{SIMPULAN DAN SARAN}

Mahasiswa dengan kecerdasan logis matematis rendah cenderung mempunyai proses berpikir komputasional karena mempunyai ciri-ciri seperti pada indikator yaitu tidak dapat mengungkapkan apa yang diketahui dalam soal kombinatorial dengan kalimat sendiri, tidak mampu mengungkapkan dengan kalimat sendiri yang ditanya dalam soal kombinatorial. Siswa dengan kecerdasan logis matematis sedang tidak bisa dikategorikan atau belum bisa diidentifikasi karena pada proses berpikir pada siswa pertama tidak bisa dikategorikan atau belum bisa diidentifikasi dan untuk siswa kedua cenderung mempunyai proses berpikirsemi konseptual karena mempunyai ciri-ciri seperti pada indikator yaitu kurang dapat mengungkapkan apa yang diketahui dalam soal kombinatorial dengan kalimat sendiri, kurang mampu mengungkapkan dengan kalimat sendiri yang ditanya dalam soal kombinatorial. Siswa dengan kecerdasan logis matematis rendah cenderung mempunyai proses berpikir konseptual karena mempunyai ciri-ciri seperti pada indikator yaitu mampu mengungkapkan apa yang diketahui dalam soal kombinatorial dengan kalimat sendiri, mampu mengungkapkan dengan kalimat sendiri yang ditanya dalam soal kombinatorial. Berdasarkan penelitian ini tentunya proses berpikir pada masing-masing mahasiswa perlu menjadi perhatian bagi pendidik dalam upaya memperbaiki proses belajar mengajar di kelas.

\section{Daftar Pustaka}

[1] Yeni and Aji, R. S., "Analisis Kemampuan Penalaran Matematis Siswa SMP Melalui Model Pembelajaran Numbered Heads Together," J. Prima, vol. 5, no. 2, pp. 73-81, 2016.

[2] Nasional, D. P., Kumpulan Permendiknas tentang Standar Nasional Pendidikan (SNP) dan Panduan KTSP. Jakarta: Direktorat Pembinaan Sekolah Menengah Atas, 2008.

[3] Ariawan, R. and Nufus, H., "Hubungan Kemampuan Pemecahan Masalah Matematis dengan Kemampuan Komunikasi Matemtis Siswa," J. THEOREMS Orig. Res. Math., vol. 1, no. 2, pp. 8291, 2017.

[4] Susandi, A. D. and Widyawati, S., "Proses Berpikir Dalam Memecahkan Masalah Logika Matematika Ditinjau Dari Gaya Kognitif Fiel Independent Dan Fiel Dependent," Numer. J. Mat. Dan Pendidik. Mat., vol. 1, no. 1, pp. 93-112, 2017.

[5] Nafi'an and Ilman, M., "Proses Berpikir Siswa Kelas V Dalam Menyelesaikan Soal Cerita Pada Pokok Bahasan Pecahan Di Sekolah Dasar Khadijah Surabaya," Gramatika, vol. 1, no. 2, pp. 115119, 2012.

[6] C. Choirudin, "Efektifitas Pembelajaran Matematika Dengan E-Learning Berbasis Schoology," masters, Universitas Terbuka, 2015. 
Numerical: Jurnal Matematika dan Pendidikan Matematika, Vol. 1 No. 2 Desember 2017, 103-114

Lilia Sinta Wahyuniar, Santi Widyawati

[7] Yanti, A. P. and Syazali, M., "Analisis Proses Berpikir Siswa dalam Memecahkan Masalah Matematika Berdasarkan Langkah-langkah Bransford Dan Stein Ditinjau Dari Adversity Quotient," Numer. J. Mat. Dan Pendidik. Mat., vol. 1, no. 1, pp. 63-74, 2016.

[8] Retna, M., Mubarokah, L., and Suhartatik, "Proses Berpikir Siswa Dalam Menyelesaikan Soal Cerita Ditinjau Berdasarkan Kemampuan Matematika," J. Pendidik. Mat. STKIP PGTI Sidoarjo, vol. 1, no. 2, pp. 71-82, 2013.

[9] Prasetyo, "Identifikasi Proses Berpikir Siswa Dalam Menyelesaikan Pernyataan Pada Materi Biologi," Bioma, vol. 4, no. 1, pp. 90-99, 2015.

[10] M. S. Anwar, "Efektifitas Pembelajaran PBL (Problem Based Learning) Terhadap Kemampuan Berpikir Kritis Dan Kreatif Siswa Materi Tiga Dimensi,” masters, Universitas Terbuka, 2015.

[11] Kuswana, W. S., Taksonomi Berpikir. Bandung: PT Remaja Rosdakarya, 2011.

[12] Gardner, H., Kecerdasan Majemuk (Teori dalam Praktek). Jakarta: Interaksara, 2013.

[13] Iskandar, Psikologi Pedidikan (Sebuah Orientasi Baru). Jakarta: Refrensi, 2012.

[14] Nashrullah, Pembelajaran Islam Berbasis Multiple Intelligences. Jakarta: STEP, 2013.

[15] Nurzaelani, M. M. and Wibowo, S., "Hubungan Antara Kecerdasan Logis-Matematis dan Komunikasi Interpersonal Dengan Hasil Belajar Mata Pelajaran Matematika (Survei Pada Peserta Didik Kelas XI SMK Geo Informatika)," J. Teknol. Pendidik. Program Studi Teknol. Pendidik. Fak. Pascasarj. UIKA Bogor, vol. 4, no. 1, pp. 56-72.

[16] Margono, S., Metodologi Penelitian Pendidikan. Jakarta: PT Rineka Cipta, 2006.

[17] Sutopo, H. B., Metodologi Penelitian Kualitatif: Dasar Teori dan Terapannya Dalam Penelitian. Surakarta: Sebelas Maret University Press, 2012.

[18] Saputro, M., "Analisis Kemampuan Pemecahan Masalah Matematika Berdasarkan LangkahLangkah Polya ditinjau dari Gaya Kognitif Siswa,” UNS, Surakarta, 2011.

[19] Prawiradilaga, Salma, D., and Siregar, E., Mozaik Teknologi Pendidikan. Jakarta: Kencana, 2007.

[20] Pane, L. Y., Kamid, and Asrial, "Proses Berpikir Logis Siswa Sekolah Dasar Bertipe Kecerdasan Logis Matematis Dalam Memecahkan Masalah Matematika," Edu-Sains, vol. 2, no. 2, pp. 14-21, 2013.

[21] Irvaniyah, I. and Akbar, R. O., "Analisis Kecerdasan Logis Matematis dan Kecerdasan Linguistik Siswa Berdasarkan Jenis Kelamin (Studi Kasus Pada Siswa Kelas XI IPA MA Mafatihul Huda)," EduMa, vol. 3, no. 1, pp. 138-159, 2014.

[22] Amstrong, T., Kecerdasan Multipel di dalam Kelas. Jakarta: Indeks, 2013.

[23] Chatib, M., Orang Tuanya Manusia. Bandung: Kaifa, 2013. 